\title{
PILOT PLANT PENGOLAHAN AIR MINUM DENGAN PROSES BIOFILTRASI DAN ULTRAFILTRASI
}

\author{
Oleh : \\ Nusa Idaman Said dan Wahyu Widayat
}

Pusat Teknologi Lingkungan, BPPT

\begin{abstract}
Until now, the drinking water companies in Indonesia still use chlorine for disinfection processes. In addition, the chlorine also uses for removal Fe, Mn and ammonia. If the raw water contains high concentration of ammonia, chlorine will react with ammonia form chloramines which have lower strength of disinfection power. The higher concentration of ammonia in raw water caused the higher consumption of chlorine. The reaction of chlorine with certain organic compounds as humic substances will to produce chloroorgano compounds like chlorophenols which become serious problems to day because trihalomethane and also chlorophenols compounds are carcinogenic substances.

To overcome the problems one of alternative is using the combination of biofiltration and ultrafiltration to process the drinking water. Biofltrations process is treatment of raw water biologically using fixed bed biofilter reactor witch filled with honeycomb plastic supporting media for removal $\mathrm{Fe}$, Mn, ammonia detergent, and also organic substances. Ultrafiltration (UF) is filtration process using hollow fiber membranes that have effective pore sizes of $0.1-0.01 \mu \mathrm{m}$. The ultrafiltration units are capable of separating some large molecular weight dissolved organics, colloids, macromolecules and suspended solids from raw water. The ultrafiltration process is designed to remove colloidalized particles in the range from 0.1-0.01 $\mu \mathrm{m}$.

By combining the biofiltration and ultrafiltration processes, hence will be got technological alternative of drinking water process which capable to degrade an organic matter, ammonia, detergent and can remove the colloidal or suspended matter effectively without chemicals instead of conventional process.
\end{abstract}

Kata Kunci : Pengolahan Air Minum, Biofiltrasi, Membran, Ultrafiltrasi, Pilot Plant

\section{PENDAHULUAN}

Masalah air baku air minum di kota-kota besar misalnya Jakarta, Surabaya, dan kota besar lainnya semakin hari kualitasnya semakin menurun. Hal ini mengakibatkan semakin mahalnya biaya produksi air baku dan pada kondisi tertentu dapat menyebabkan PAM Jaya tidak dapat menghasilkan air bersih yang aman sesuai dengan standar yang di tetapkan Menteri Kesehatan (Kompas, 7 juni 1995). Dari hasil pemantauan yang dilakukan oleh PAM pada bulan September 2000 terhadap air baku (intake water) di instalasi PAM Cilandak menunjukkan bahwa konsentrasi amoniak bervariasi hingga mencapai sekitar 2,0 mg/l, dimana nilai konsentrasi tersebut telah melampaui ambang batas peruntukkan air baku air minum yakni sebesar $1 \mathrm{mg} / \mathrm{l}$ menurut Kep. Gub. KDKI Jakarta No. 582 th 1995.

Dilihat dari konsentrasi zat pencemar amoniak dalam air baku cukup tinggi, maka PAM di Indonsia khususnya PAM di DKI Jakarta menggunakan senyawa khlor (gas khlor atau kalsium hipoklorit) yang selain untuk proses desinfeksi juga digunakan untuk menghilangkan senyawa logam $\mathrm{Fe}, \mathrm{Mn}$, serta amoniak. Dengan semakin besarnya konsentrasi senyawa amoniak dalam air baku, maka amoniak akan bereaksi dengan khlor menjadi khloramine yang daya desinfeksinya lebih lemah. Hal ini akan mengakibatkan konsumsi khlor akan menjadi lebih besar sehingga biaya operasi menjadi lebih tinggi.

Selain itu dengan semakin besarnya konsentrasi senyawa khlor yang digunakan, maka hasil samping yang dihasilkan seperti terbentuknya senyawa trihalometan dan khlorophenol juga semakin besar. Senyawasenyawa tersebut dapat mengakibatkan penyakit kanker (carcinogen). Oleh karena itu zat pencemar amoniak dan juga senyawa organik harus dihilangkan.

Trihalomethane adalah senyawa organik derivat methan $\left(\mathrm{CH}_{4}\right)$ yang mana tiga buah atom Hidrogen $(\mathrm{H})$ nya diganti oleh atom halogen yakni khlor (Cl), Brom (Br), lodium (I). Beberapa senyawa trialomethane yang umum dijumpai antara lain yakni khloroform $\left(\mathrm{CHCl}_{3}\right)$, dibromokhloromethan $\left(\mathrm{CHBr}_{2} \mathrm{Cl}\right)$, bromoform $\left(\mathrm{CHBr}_{3}\right)$. Jumlah total ke empat senyawa tersebut sering disebut total trihalomethan 
(TTHM). Selain ke empat senyawa tersebut di atas masih ada beberapa senyawa trihalomenthan lainnya tetapi biasanya kurang stabil (JICA:" Water Supply Engineering VOL.I").

Pada tahun 1976, National Cancer Institute mengumumkan bahwa senyawa khloroform yang merupakan senywa THMs yang paling umum, dengan dosis yang cukup tinggi dapat menyebabkan kanker terhadap tikus. Sekarang ini, hampir tidak ada keraguan lagi bahwa senyawa THMs khususnya khloroform adalah senyawa yang sangat potensial dapat menyebabkan kanker.

Air sungai yang mengandung precursor THMs ini, kemudian diolah untuk dijadikan air minum masyarakat di daerah hilir. Kemudian Senyawa precursor THMs tersebut bereaksi dengan senyawa khlor yang digunakan untuk proses disinfeksi sehingga terbentuklah senyawa trihalomethanes dan senyawa halogen organik lainnya. Selain itu, dengan semakin besarnya kandungan amonia dalam air baku maka amonia akan bereaksi dengan khlor membentuk senyawa khloramine yang mempunyai daya disinfeksi yang lebih rendah. Sebagai akibatnya konsumsi senyawa khlor yang digunakan akan bertambah besar, dan dengan semakin besarnya konsentrasi khlor yang digunakan maka kemungkinan akan terbentuknya THMs juga semakin besar.

Pengolahan air minum dengan proses biofiltarsi dan ultrafilrasi adalah gabungan proses biofitrasi yaitu proses pengolahan air baku (air sungai) secara biologis sistem biofilter menggunakan media plastik sarang tawon untuk menghilangkan polutan organik, amoniak, deterjen, zat besi dan mangan dikombinasi dengan teknologi membran ultrafiltrasi yang dapat menyaring padatan dengan ukuran 0,01 mikron. Dengan menggabungkan proses biofiltrasi dengan teknologi membran ultra filtrasi (UF) maka akan didapatkan suatu alternatif teknologi pengolahan air minum yang dapat menurunkan kandungan zat organik dan amoniak tanpa menggunakan bahan kimia seperti pada proses konvesional.

\section{PRINSIP PENGOLAHAN}

\subsection{Penghilangan Zat Organik}

Pengolahan air secara biologis merupakan suatau proses penguraian bahan-bahan pencemar, baik yang terlarut maupun yang tidak terlarut menjadi bentuk yang lain berupa gas atau padatan (N.J. Horan, 1990). Hasil dari transformasi tersebut dipengaruhi oleh kondisi lingkungan pada saat proses berlangsung yaitu kondisi aerobik dan anaerobik.
Proses pengolahan biologis secara aerobik merupakan suatu proses yang membutuhkan oksigen untuk menunjang berlangsungnya proses metabolisme biokimia oleh bakteri dalam peruraian bahan-bahan organik menjadi bentuk yang lebih sederhana yaitu $\mathrm{CO}_{2}, \mathrm{H}_{2} \mathrm{O}$, senyawa-senyawa oksida seperti nitrat, sulfat, phosphat dan terbentuknya massa sel yang baru.

Pada pengolahan secara biologis, pertumbuhan mikroorganisme dapat dilakukan secara melekat pada permukaan media penyangga (attached growth), yakni suatu proses pengolahan dimana senyawa-senyawa organik atau senyawa-senyawa lainnya yang terdapat dalam air diuraikan oleh mikroorganisme yang melekat pada permukaan media penyangga menjadi senyawa yang lebih sederhana serta membentuk biomasa atau selsel baru.

Kondisi lingkungan biokimia yang sangat mempengaruhi berlangsungnya proses transformasi adalah kondisi lingkungan aerob dan kondisi lingkungan anaerob. Jika lingkungan tersebut mengandung cukup oksigen terlarut maka dinamakan lingkungan aerob. Pada kondisi lingkungan anaerob kadar oksigen terlarut tidak ada. Selain kedua lingkungan tersebut ada lingkungan yang dinamakan lingkungan anoksik, yaitu bila kadar oksigen terlarut dalam konsentrasi yang rendah.

Zat Organik dapat disisihkan secara biologi yang tergantung dari jumlah oksigen terlarut, jenis mikroorganisme dan jumlah zat pengurai (Polii,1994). Adanya $\mathrm{O}_{2}$ menyebabkan proses oksidasi aerob dapat berlangsung, bahan - bahan organik akan dirubah menjadi produk produk akhir yang relatif stabil dan sisanya akan disintesis menjadi mikroba baru. Secara umum dapat dilihat pada persamaan di bawah ini :

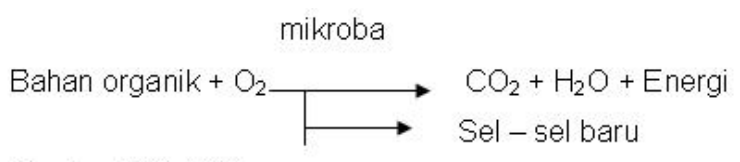

(Sumber : Polii, 1994)

Mikroorganisme mengalami proses metabolisme yang terdiri dari proses katabolisme dan anabolisme. Proses anabolisme memerlukan energi (reaksi endergonik) dan terjadi pada proses sintesa mikroorganisme, sedangkan proses katabolisme yang terjadi pada proses oksidasi dan respirasi merupakan reaksi eksergonik karena melepaskan energi (Reynolds,1985). Proses transformasi substrat berlangsung dalam suatu kelompok protein yang berperan sangat penting dalam proses biologis, yaitu enzim yang bersifat katalis. 
Proses metabolisme pada mikroorganisme dapat dilihat dibawah ini (Metcalf dan Eddy,1991) :

\section{Oksidasi}

$\mathrm{COHNS}+\mathrm{O}_{2}+$ bakteri $\longrightarrow \mathrm{CO}_{2}+\mathrm{NH}_{3}+$ produk

(Materi organik) + energi akhir

\section{Sintesa}

COHNS $+\mathrm{O}_{2}+$ bakter $\longrightarrow+$ energi (Materi Organik) (Sel Bakteri Baru)

$\underline{\text { Respirasi }}$

$$
\begin{aligned}
\mathrm{C}_{5} \mathrm{H}_{7} \mathrm{NO}_{2}+5 \mathrm{O}_{2} \longrightarrow & 5 \mathrm{CO}_{2}+\mathrm{NH}_{3}+2 \mathrm{H}_{2} \mathrm{O} \\
+ & \text { energi }
\end{aligned}
$$

\subsection{Penghilangan Amoniak}

Di dalam proses biofiltrasi, senyawa amoniak akan diubah menjadai nitrit, kemudaian senyawa nitrit akan diubah menjadi nitrat. Mekanisme proses penguraian senyawa amoniak yang terjadi pada lapisan biofilm secara sederhana dapat diilustrasikan seperti pada Gambar 1.

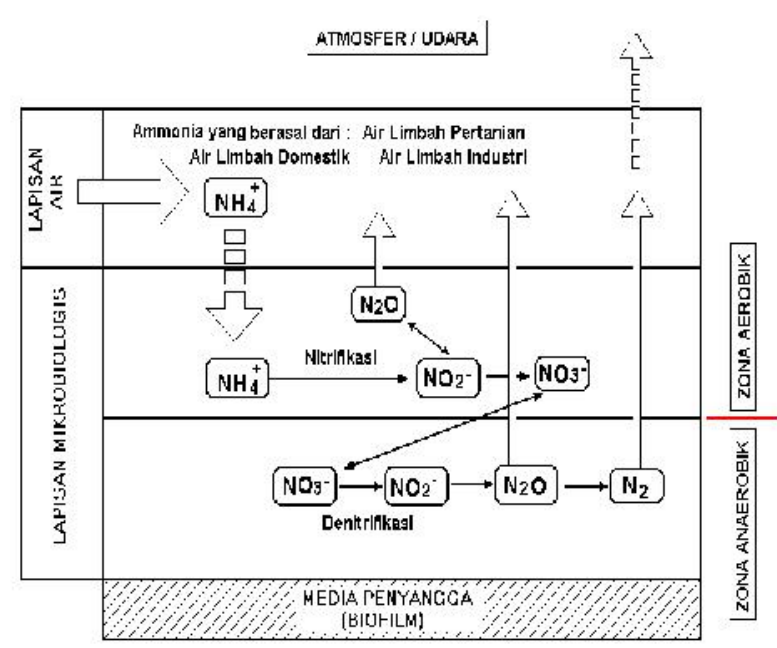

Gambar 1 : Ilustrasi Dari Mekanisme Proses Penguraian Amoniak Di Dalam Biofilm

Lapisan terluar media penyangga adalah lapisan tipis zona aerobik, senyawa amoniak dioksidasi dan diubah ke dalam bentuk nitrit. Sebagian senyawa nitrit ada yang diubah menjadi gas dinitrogen oksida $\left(\mathrm{N}_{2} \mathrm{O}\right)$ dan ada yang diubah menjadi nitrat. Proses yang terjadi tersebut dinamakan proses nitrifikasi.
Semakin lama, lapisan biofilm yang tumbuh pada media penyangga tersebut semakin tebal sehingga menyebabkan oksigen tidak dapat masuk ke dalam lapisan biofilm yang mengakibatkan terbentuknya zona anaerobik. Pada zona anaerobik ini, senyawa nitrat yang terbentuk diubah ke dalam bentuk nitrit yang kemudian dilepaskan menjadi gas nitrogen $\left(\mathrm{N}_{2}\right)$. Proses demikian tersebut dinamakan proses denitrifikasi.

Proses nitrifikasi menurut Gardy \& Lim (1980) didefinisikan sebagai konversi nitrogen ammonium $\left(\mathrm{N}-\mathrm{NH}_{4}\right)$ menjadi nitrit $\left(\mathrm{N}-\mathrm{NO}_{2}\right)$ yang kemudian menjadi nitrat $\left(\mathrm{N}-\mathrm{NO}_{3}\right)$ yang dilakukan oleh bakteri autotropik dan heterotropik. Proses nitrifikasi ini dapat dilihat dalam dua tahap yaitu :

Tahap nitritasi, merupakan tahap oksidasi ion ammonium $\left(\mathrm{NH}_{4}{ }^{+}\right)$menjadi ion nitrit $\left(\mathrm{NO}_{2}^{-}\right)$yang dilaksanakan oleh bakteri nitrosomonas menurut reaksi berikut :

$\mathrm{NH}_{4}{ }^{+}+1 / 2 \mathrm{O}_{2}+\mathrm{OH}^{-} \rightarrow \mathrm{NO}_{2}^{-}+\mathrm{H}^{+}+2 \mathrm{H}_{2} \mathrm{O}+59,4$ Kcal

Nitrosomonas

Reaksi ini memerlukan $3,43 \mathrm{gr} \mathrm{O}_{2}$ untuk mengoksidasi $1 \mathrm{gr}$ nitrogen menjadi nitrit.

Tahap nitrasi, merupakan tahap oksidasi ion nitrit menjadi ion nitrat $\left(\mathrm{NO}_{3}{ }^{-}\right)$yang dilaksanakan oleh bakteri nitrobacter menurut reaksi berikut :

$\mathrm{NO}_{2}{ }^{-}+1 / 2 \mathrm{O}_{2} \rightarrow \mathrm{NO}_{3}{ }^{-}+18 \mathrm{Kcal}$ Nitrobacter

Reaksi ini memerlukan 1,14 gr $\mathrm{O}_{2}$ untuk mengoksidasi $1 \mathrm{gr}$ nitrogen menjadi nitrat. Secara keseluruhan proses nitrifikasi dapat dilihat dari persamaan berikut :

$$
\mathrm{NH}_{4}^{+}+2 \mathrm{O}_{2} \rightarrow \mathrm{NO}_{3}^{-}+2 \mathrm{H}^{+}+\mathrm{H}_{2} \mathrm{O}
$$

Kedua reaksi di atas disebut dengan reaksi eksotermik (reaksi yang menghasilkan energi). Jika kedua jenis bakteri tersebut ada, baik di tanah maupun di perairan, maka konsentrasi nitrit akan menjadi berkurang karena nitrit dibentuk oleh bakteri nitrosomonas yang akan dioksidasi oleh bakteri nitrobacter menjadi nitrat.

Kedua bakteri ini dikenal sebagai bakteri autotropik yaitu bakteri yang dapat mensuplai karbon dan nitrogen dari bahan-bahan anorganik dengan sendirinya. Bakteri ini menggunakan energi dari proses nitrifikasi untuk membentuk sel sintesa yang baru. Sedangkan bakteri heterotropik merupakan bakteri yang membutuhkan bahan-bahan organik untuk membangun protoplasma. Walaupun bakteri nitrifikasi autotropik keberadaannya di alam lebih banyak, proses nitrifikasi dapat juga dilakukan 
oleh bakteri jenis heterotropik (Arthobacter) dan jamur (Aspergillus) (Verstraete and Alexander, 1972).

Disamping itu dengan oksigen yang ada, maka senyawa $\mathrm{N}-\mathrm{NH}_{4}$ yang ada diperairan akan dioksidasi menjadi nitrat. Tetapi mengingat kebutuhan $\mathrm{O}_{2}$ yang cukup besar, maka akan terjadi penurunan oksigen di dalam perairan tersebut sehingga akan terjadi kondisi septik.

Pada proses pengolahan senyawa $\mathrm{N}-\mathrm{NH}_{4}$ secara biologis kebutuhan $\mathrm{O}_{2}$ cukup besar, sehingga kebutuhan $\mathrm{O}_{2}$ yang tinggi dapat dipenuhi dengan cara memperbesar transfer $\mathrm{O}_{2}$ ke dalam instalasi pengolahan. Pada reaktor lekat ini, transfer $\mathrm{O}_{2}$ yang besar dapat diperoleh dengan cara menginjeksikan udara ke dalam reaktor. Dengan adanya injeksi udara diharapkan kontak antara gelembung udara dan air yang akan diolah dapat terjadi.

\subsection{Reaktor Biologis Unggun Tetap (Fixed bed Biofilter)}

Struktur reaktor biofilter menyerupai saringan (filter) yang terdiri atas susunan atau tumpukan bahan penyangga yang disebut dengan media penyangga yang disusun baik secara teratur maupun acak di dalam suatu bejana. Fungsi media penyangga adalah sebagai tempat tumbuh dan berkembangnya mikroorganisme yang akan melapisi permukaan media membentuk lapisan massa yang tipis (biofilm). Mikroorganisme ini menguraikan bahan organik yang ada dalam air. Ketebalan lapisan biofilm menyebabkan difusi oksigen berkurang terhadap lapisan terdalam biofilm tersebut sehingga dapat menyebabkan terjadinya kondisi anaerobik pada lapisan permukaan media (Metcalf \& Eddy, 1991). Air yang diolah akan dikontakkan dengan sejumlah mikroba dalam bentuk lapisan film (slime) yang melekat pada permukaan media.

Media penyangga merupakan salah satu kunci pada proses biofilter. Efektifitas dari suatu media tergantung pada :

- Luas permukaan, semakin luas permukaan media maka semakin besar jumlah biomassa per unit volume.

- Volume rongga, semakin besar volume rongga/ruang kosong maka semakin besar kontak antara substrat dalam air buangan dengan biomassa yang menempel

Faktor terpenting yang mempengaruhi pertumbuhan bakteri pada media penyangga adalah kecepatan aliran serta bentuk dan jenis konfigurasi media. Media yang digunakan dapat berupa kerikil, batu pecah (split), media plastik (polivinil chlorida), dan partikel karbon aktif dan lainnya. Media yang sering digunakan pada proses biologis khususnya biofiter adalah media plastik yang terbuat dari PVC (Gabriel Bitton, 1994). Kelebihan dalam penggunaan media plastik ini antara lain :

- Ringan serta mempunyai luas permukaan spesifik besar (luas permukaan per satuan volume) berkisar antara sebesar 85-226 $\mathrm{m}^{2} / \mathrm{m}^{3}$.

- Volume rongga yang besar dibanding media lainnya (hingga 95\%) sehingga resiko kebuntuan kecil.

$\mathrm{Di}$ dalam reaktor biofilter, mikroorganisme tumbuh melapisi keseluruhan permukaan media dan pada saat beroperasi air mengalir melalui celah-celah media dan berhubungan langsung dengan lapisan massa mikroba (biofilm). Mekanisme perpindahan massa yang terjadi pada permukaan suatu media dinyatakan sebagai berikut :

- Diffusi substansi air buangan dari cairan induk ke dalam massa mikroba yang melapisi media.

- Reaksi peruraian bahan organik maupun anorganik oleh mikroba.

- Diffusi produk peruraian ke luar kecairan induk limbah.

Permukaan media yang kontak dengan nutrisi yang terdapat dalam air buangan ini mengandung mikroorganisme yang akan membentuk lapisan aktif biologis. Disamping itu oksigen terlarut juga merupakan faktor pembentukan lapisan film. Proses awal pertumbuhan mikroba dan pembentukan lapisan film pada media membutuhkan waktu beberapa minggu, yang dikenal dengan "proses pematangan". Pada awalnya tingkat efisiensi penjernihan sangat rendah yang kemudian akan mengalami peningkatan dengan terbentuknya lapisan film (N.J. Horan, 1990).

\subsection{Teknologi Membrane di dalam Pengolahan Air}

Perkembangan teknologi dalam pengolahan air telah berkembang demikian pesatnya, yang mana diharapkan dapat menjadi jawaban untuk sebagian dari permasalahan yang ada dalam pengolahan air bersih. Salah satu teknologi yang dikembangkan adalah teknologi penyaringan atau filtrasi dengan menggunakan membran.

Teknologi menggunakan membran sebenarnya bukanlah suatu teknologi yang baru ditemukan, karena membran itu sendiri telah digunakan semenjak lebih dari 50 tahun yang lalu. Adapun jenis membran yang tersedia saat ini dibagi menjadi 4 kelompok besar disesuaikan dengan ukuran dari tingkat penyaringan atau sering disebut dengan istilah 'Filtration degree". Tingkat-tingkat penyaringan yang dimaksud adalah sebagai berikut : 
* Micro Filtration (MF)

* Ultra Filtration (UF)

* Nano Filtration (NF)

* Hyper Filtration / Reverse Osmosis (RO)

Distribusi ukuran partikel yang dapat dipisahkan sesuai dengan tingkatan proses filtrasi dapat dilihat pada Gambar 2.

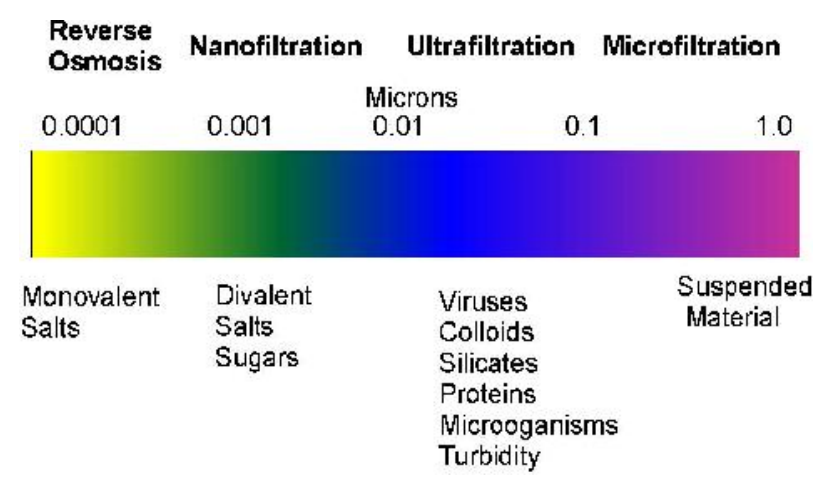

Gambar 2 : Distribusi Ukuran Partikel Yang Dapat Dipisahkan Sesuai Dengan Tingkatan Proses Filtrasi

Sesuai dengan nama dan tingkatan dari 'Filtration Degree", diharapkan akan didapatkan air dengan tingkat kebersihan tertentu pula. Misalnya pada Micro Filtration / MF dengan derajad penyaringan (Filtration Degree) sekitar 1 micron, diharapkan sebagian besar dari padatan tersuspensi (suspended material) akan tersaring. Dan sudah bukan menjadi suatu hal yang baru bahwa dengan menggunakan teknologi membran ini telah dimungkinkan merubah air laut menjadi air tawar, yaitu dengan menggunakan membran Reverse Osmosis (RO).

Seperti telah dijelaskan di atas bahwa baku mutu air baku yang semakin memburuk mengharuskan kita untuk mencari teknologi alternatif guna menjawab permasalahanpermasalahan yang ada. Salah satu masalah yang cukup serius adalah semakin buruknya kualitas air baku akibat pencemaran limbah organik misalnya oleh air limbah domestik. Dengan kondisi air baku seperti tersebut di atas tidak dapat diatasi dengan pengolahan air minum secara konvensional. Salah satu alternatif teknologi di masa depan adalah menggunakan kombinasi proses biologis misalnya biofilter dengan teknologi membran ultra filtrasi (UF).

\section{PENGOLAHAN AIR MINUM DENGAN PROSES BIOFILTRASI DAN ULTRA FILTRASI}

Dengan menggabungkan proses biofiltrasi seperti yang telah dilakukan pada percobaan di atas dengan teknologi membran ultra filtrasi (UF) maka akan didapatkan suatu alternatif teknologi pengolahan air minum yang dapat menurunkan kandungan zat organik dan amoniak tanpa menggunakan bahan kimia seperti pada proses konvesional. Ilustrasi proses pengolahan air minum dengan kombinasi proses biofiltrasi dan proses ultra filtrasi dapat dilihat sepertri pada Gambar 3.

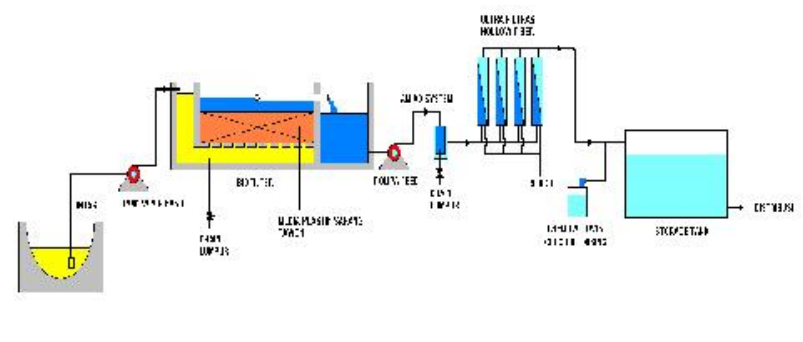

Gambar 3 : llustrasi Proses Pengolahan Air Minum Dengan Kombinasi Proses Biofilter Dan Proses Filtrasi Membrane

Air baku dari saluran intake dipompa ke reaktor biofilter dengan menggunakan pompa air baku. Reaktor biofilter diisi dengan media biofilter dari bahan plastik tipe sarang tawon. Di dalam reaktor biofilter tersebut senyawa polutan yang ada di dalam air baku misalnya zat organik, amoniak, zat besi , mangan, deterjen dan senyawa polutan lain dapat diuraikan secara biologis. Selain itu padatan tersuspensi yang ada di dalam air baku dapat diendapakan. Air yang keluar dari biofilter selanjutnya di tampung ke bak penampung, selanjutnya dipompa ke automatik filter yang dapat menyaring kontoran sampai 10-50 mikron. Dari filter automatik air dilairkan ke unit ultra filtrasi yang dapat menyaring sampai ukuran 0,01 mikron.

Unit ultra filtrasi menggunakan modul membrane tipe hollow fiber. Air yang keluar dari unit ultra filtrasi dilairkan ke bak penampung air olahan sambil diinjeksi dengan larurtan kaporit untuk proses disinfeksi dan selanjutnya dilairkan ke sistem distribusi.

Dengan sistem kombinasi biofiltrasi dan ultra filtrasi mempunyai beberapa kelebihan antara lain adalah :

口 Penggunaan proses biofiltrasi dapat menghilangkan senyawa polutan yang tidak bisa dihilangkan dengan proses konvensional misalnya, zat organik, amoniak, deterjen, pestisida, dll. Senyawa tersebut dapat diuraikan dengan proses biologis secara alami (natural).

- Tanpa menggunakan bahan koagulan dan flokulan. Dalam hal ini bahan yang digunakan hanya larutan kaporit untuk mendapatkan konsentrasi sisa klor yang cukup agar tidak terjadi rekontaminasi. 
- Dengan proses ultra filtrasi dapat dihasilkan air olahan dengan kualitas yang sangat baik dan stabil.

- Bentuknya lebih kompak sehingga luas area yang dibutuhkan lebih kecil.

- Sangat fleksibel jika ada penambahan kapasitas.

\section{PILOT PLANT PENGOLAHAN AIR MINUM DENGAN PROSES BIOFILTRASI DAN ULTRAFILTRASI}

\subsection{Proses Biofiltrasi dan Ultrafiltrasi}

Proses pengolahan yang digunakan adalah Secara garis besar proses pengolahan minum dengan kombinasi proses kombinasi proses biofiltrasi dan ultrafiltrasi dapat dilihat pada lampiran Gambar 4.

Air baku yang berasal dari sungai dipompa dan dialirkan ke unit biofiltrasi untuk proses pengolahan awal. Proses biofiltrasi ini dilakukan dengan cara mengalirkan air baku ke dalam bak yang diisi dengan media biofilter yang berupa plastik tipe sarang tawon. Dengan mengalirkan air baku ke dalam media biofilter maka pada permukaan media akan terbentuk lapisan mikroorganisme yang akan menguraikan senyawa amonia, polutan organik, deterjen dan lainnya serta untuk mengendapkan partikel lumpur. Waktu tinggal di dalam bak biofilter adalah sekitar 2 jam.

Air limpasan dari biofilter selanjutnya ditampung kedalam bak penampung air baku. Dari bak penampung air baku, selanjutnya dipompa ke unit proses Ultra Filtrasi yang dapat menyaring partikel sampai ukuran 0,1-0,01 mikron.

Unit ultra filtrasi terdiri dari pompa feed, mikro strainer yang dapat penyaring partikel sampai ukuran 50-100 mikron, serta menggunakan modul membrane tipe hollow fiber Hydrophilic modified Polyacrylonitryl yang dapat menyaring partikel sampai ukuran 0,01 mikron. Dengan penyaringan ultrafiltrasi secara teknis bakteri sudah dapat disaring. Air yang keluar dari unit ultrafiltrasi diinjeksi dengan kaporit untuk membunuh kuman yang mungkin masih ada di dalam air, selanjtnya dialirkan ke bak penampung air olahan. Dari bak penampung air dipompa sistem distribusi.

\subsection{Keunggulan Proses Biofiltrasi dan Ultrafiltrasi}

Dengan sistem kombinasi biofiltrasi dan ultrafiltrasi mempunyai beberapa kelebihan antara lain yakni :

$>$ Penggunaan proses biofiltrasi dapat menghilangkan senyawa polutan yang tidak bisa dihilangkan dengan proses konvensional misalnya, zat organik, amoniak, deterjen, pestisida, dll. Senyawa tersebut dapat diuraikan dengan proses biologis secara alami (natural)

> Tanpa menggunakan bahan koagulan dan flokulan. Dalam hal ini bahan yang digunakan hanya larutan kaporit untuk mendapatkan konsentrasi sisa klor yang cukup agar tidak terjadi rekontaminasi.

$>$ Dengan proses ultra filtrasi dapat dihasilkan air olahan dengan kualitas yang sangat baik dan stabil.

$>$ Bentuknya lebih kompak sehingga luas area yang dibutuhkan lebih kecil.

$>$ Sangat fleksibel jika ada penambahan kapasitas.

> Dapat dioperasikan dengan sederhana dan handal, manual flushing dilakukan sesuai kebutuhan dengan indikator pressure gauge.

$>$ Biaya investasi yang ekonomis.

\subsection{Aplikasi}

Proses biofiltrasi dan ultrafiltrasi dapat digunakan untuk mengolah air baku yang tidak memenuhi syarat air baku air minum atau air baku yang sudah tercemar menjadi air minum tanpa menggunakan bahan kimia.

\subsection{Spesifikasi Teknis Unit Biofiltrasi Dan Ultrafiltrasi Kapasitas 180 M $^{3}$ Per Hari}

Spesifikasi Teknis Unit Biofiltrasi Dan Ultrafiltrasi kapasitas $180 \mathrm{M}^{3}$ per hari daoat dilihat pada Tabel 1.

Tabel 1 : Spesifikasi Teknis Unit Biofiltrasi Dan Ultrafiltrasi Kapasitas $180 \mathrm{~m}^{3}$ per Hari

\begin{tabular}{|c|c|c|}
\hline No & \multicolumn{2}{|c|}{ Diskripsi Peralatan } \\
\hline 1 & \multicolumn{2}{|c|}{ Pompa Biofiltrasi } \\
\hline & $\begin{array}{l}\text { Tipe } \\
\text { Merek } \\
\text { Kapasitas } \\
\text { Bahan } \\
\text { Total Head } \\
\text { Listrik } \\
\text { Diamter Outlet } \\
\text { Jumlah } \\
\end{array}$ & $\begin{array}{l}\text { : Pompa celup/ submersible } \\
: \text { HCP Model F-05AF } \\
: 0,1-0,22 \mathrm{~m}^{3} / \text { menit } \\
: \text { Polimer atau Stainless steel } \\
: 8-11,5 \mathrm{~m} \\
: 0,5 \mathrm{KW}, 220 \mathrm{~V} \\
: 2 " \\
: 1 \text { unit }\end{array}$ \\
\hline 2 & $\begin{array}{l}\text { Reaktor Biofilt } \\
\text { Material } \\
\text { Volume } \\
\text { Waktu Tinggal } \\
\text { Dimensi Bak } \\
\text { Perlengkapan } \\
\text { lumpur } \\
\text { Junlah }\end{array}$ & $\begin{array}{l}\text { si } \\
: \text { Figerglass (FRP) } \\
: 9000 \text { liter } \\
: 2-3 \text { jam } \\
: 150 \mathrm{~cm} \times 300 \mathrm{~cm} \times 220 \mathrm{~cm} \\
: \text { Bak penenang, ruang } \\
\text { dan kran penguras lumpur. } \\
: 1 \text { unit }\end{array}$ \\
\hline 3 & Media Sarang Tawon & $\begin{array}{l}\text { won } \\
\text { : PVC sheet }\end{array}$ \\
\hline
\end{tabular}




\begin{tabular}{|c|c|c|}
\hline & $\begin{array}{l}\text { Ketebalan } \\
\text { Luas Spsesifik } \\
\text { Diameter lubang } \\
\text { Warna } \\
\text { Porositas Rongga } \\
\text { Volume media }\end{array}$ & $\begin{array}{l}: 0,15-0,23 \mathrm{~mm} \\
: 150-200 \mathrm{~m}^{2} / \mathrm{m}^{3} \\
: 3 \mathrm{~cm} \times 3 \mathrm{~cm} \\
: \text { bening transparan. } \\
: 0,98 \\
: 3,24 \mathrm{~m}^{3}\end{array}$ \\
\hline 4 & $\begin{array}{l}\text { Bak Penampang } \\
\text { Volume } \\
\text { Bahan } \\
\text { Kapasitas } \\
\text { Jumlah }\end{array}$ & $\begin{array}{l}\text { Antara } \\
: 5000 \text { liter } \\
: \text { Polyethylene }(\mathrm{PE}) \\
: 0,1-0,22 \mathrm{~m}^{3} / \text { menit } \\
: 1 \text { unit }\end{array}$ \\
\hline 5 & $\begin{array}{l}\text { Pompa Feed Ultr } \\
\text { Brand } \\
\text { Kapasitas } \\
\text { Bahan } \\
\text { Head } \\
\text { Tekanan maks } \\
\text { Listrik } \\
\text { Jumlah }\end{array}$ & $\begin{array}{l}\text { afiltrasi } \\
: \text { CNP } \\
: 100-120 \text { liter per menit } \\
: \text { Stainless steel } \\
: 30 \mathrm{~m} . \\
: 3 \mathrm{BAR} \\
: 0,5 \mathrm{KW}, 220 \mathrm{~V} \\
: 1 \text { unit }\end{array}$ \\
\hline 6 & $\begin{array}{l}\text { Mikro Strainer } \\
\text { Merk } \\
\text { Diameter } \\
\text { Tinggi } \\
\text { Kapasitas } \\
\text { Fitration Degree } \\
\text { Bahan } \\
\text { Jumlah }\end{array}$ & $\begin{array}{l}:- \\
: 8 \text { “ } \\
: 60 \mathrm{~cm} \\
: 6-8 \mathrm{~m}^{3} \text { per jam } \\
: 75 \text { micron } \\
: \text { Stainless Steel } \\
: 1 \text { unit }\end{array}$ \\
\hline 77 & $\begin{array}{l}\text { Unit Ultra Filtratic } \\
\text { Merek } \\
\text { Membrane } \\
\text { Material } \\
\text { Housing } \\
\text { Diemesi Membran } \\
\text { Derajad Filtrasi } \\
\text { Jumlah Membrane } \\
\text { Back wash } \\
\text { Acessories } \\
\text { kontrol dengan tim } \\
\text { Skid } \\
\text { Kapasitas Total } \\
\text { Jumlah }\end{array}$ & $\begin{array}{l}\text { on ( UF ) } \\
: \text { - } \\
: \text { Hollow Fiber } \\
: \text { Hydrophilic modified Poly } \\
\text { Acrylonitrile (PAN) } \\
: \text { Stainless Steel } \\
\text { ee : Dia. } 4 \text { " panjang } 40 \text { “ } \\
: 0.10-0.01 \text { micron } \\
\quad: 10 \text { unit } \\
\quad: \text { Otomatis } \\
: 4 \text { buah Solenoid valve } \\
\text { ner } \\
\quad \text { Carbon Steel } \\
: 140-180 \mathrm{~m}^{3} \text { per hari } \\
: 1 \text { set }\end{array}$ \\
\hline 8 & $\begin{array}{l}\text { Pompa Back Was } \\
\text { Brand } \\
\text { Kapasitas } \\
\text { Bahan } \\
\text { Head } \\
\text { Tekanan maks } \\
\text { Listrik } \\
\text { Jumlah }\end{array}$ & $\begin{array}{l}\text { sh Ultrafiltrasi } \\
\qquad \text { : CNP } \\
\quad: 100-120 \text { liter per menit } \\
\text { : Stainless steel } \\
: \text { : } 30 \mathrm{~m} . \\
\quad: 3 \mathrm{BAR} \\
\quad: 0,5 \mathrm{KW}, 220 \mathrm{~V} \\
: 1 \text { unit }\end{array}$ \\
\hline 9 & $\begin{array}{l}\text { Pompa Dosing } \\
\text { Tipe } \\
\text { Tekanan } \\
\text { Kapasitas } \\
\text { Pump head } \\
\text { Diaphragm } \\
\text { Jumlah }\end{array}$ & $\begin{array}{l}\text { : Chemtech 100/030 } \\
: 7 \text { Bars } \\
: 4.7 \mathrm{It} / \text { hour } \\
: \text { SAN } \\
\text { : Hypalon } \\
\text { : I unit }\end{array}$ \\
\hline 10 & $\begin{array}{l}\text { Chemical Tank } \\
\text { Model } \\
\text { Volume } \\
\text { Dimension } \\
\text { Material of Contr }\end{array}$ & $\begin{array}{l}: \text { - } \\
: 50 \text { liter } \\
: \varnothing 50 \mathrm{~cm}, \mathrm{H} 60 \mathrm{~cm} \\
\text { : Polvethylene (PE) }\end{array}$ \\
\hline
\end{tabular}

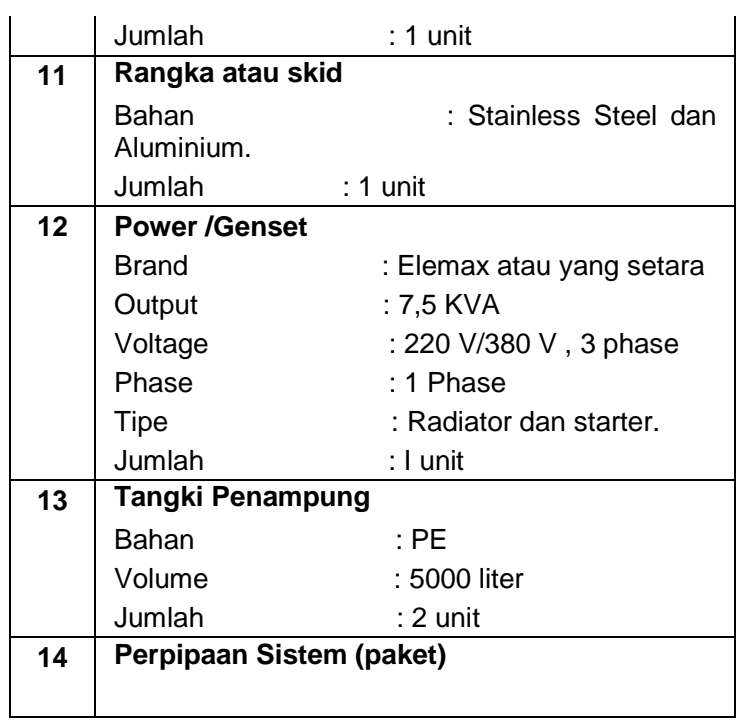

\subsection{Hasil Uji Coba Pilot Plant Pengolahan Air Minum Dengan Proses Biofiltrasi dan Ultrafiltrasi}

\subsubsection{Pengaruh Waktu Tinggal Hidrolis (WTH) Terhadap Efisiensi Penghilangan Kekeruhan}

Efisiensi penghilangan kekeruhan dalam hubungannya dengan waktu tinggal ditunjukkan pada Gambar 5. Pada hari pertama sampai dengan hari ke 6 adalah proses start-up. Waktu tinggal pada awal proses ini adalah 4 jam. Pengaturan waktu tinggal hidrolis dilakukan dengan mengatur debit air limbah yang dialirkan ke reaktor biofiltrasi ultrafiltrasi. Efisiensi proses biofiltrasi yang dihasilkan pada kondisi ini kecenderungannya naik dari hari pertama $37 \%$ sampai dengan hari ke 6 yaitu $78 \%$. Kecenderungan kenaikan ini disebabkan antara lain karena proses masih belum stabil. Sedangkan untuk efisiensi total biofiltrasi ultrafiltrasi berkisar 88-97\%.

Hari ke 7 sampai dengan hari ke 12 waktu tinggal diatur 3 jam. Pada kondisi ini efisiensi penghilangan kekeruhan untuk proses biofiltrasi relatif konstan sekitar $65 \%$. Untuk efisiensi total proses biofiltrasi ultra filtrasi juga relatif konstan sekitar $99 \%$.

Hari ke 13 sampai dengan hari ke 17 waktu tinggal diatur 2 jam. Pada kondisi ini efisiensi penghilangan kekeruhan untuk proses biofiltrasi kecenderungannya naik dari 39\% sampai $67 \%$. Kenaikan ini kemungkinan disebabkan karena proses pembentukan lapisan biofilm pada media biofilter sehingga proses filtrasi menjadi semakin baik, efisiensi penghilangan kekeruhan meningkat. Untuk efisiensi total proses biofiltrasi ultra filtrasi juga relatif konstan sekitar 99\%.

Sedangkan pada hari ke 18 sampai dengan hari ke 22 waktu tinggal diatur lebih 
singkat lagi yaitu 1 jam. Terlihat pada hari pertama saat pengubahan waktu tinggal, efisiensi penghilangan kekeruhan untuk biofltrasi menurun tajam. Ini kemungkinan disebabkan karena perubahan beban secara tiba-tiba. Untuk selanjutnya kecenderungan efisiensi biofiltrasi meningkat dari hari ke hari. Pada kondisi waktu tinggal 1 jam ini efisiensi penghilangan kekeruhan gabungan biofiltrasi ultra filtrasi juga relatif konstan berkisar 95\%.

Dari grafik terlihat kalau semakin singkat waktu tinggal hidrolis, efisiensi penghilangan kekeruhan semakin kecil untuk biofiltrasi. Sedangkan untuk gabungan kedua sistem efisiensinya tidak ada perubahan yang berarti. Ini dapat disimpulkan bahwa ultrafiltrasi berperan besar dalam menghilangkan kekeruhan. Walaupun konsentrasi kekeruhan yang masuk ke sistem ultrafiltrasi berubah-ubah, air hasil olahan kekeruhannya stabil.

Efisiensi total sistem dalam menghiklangkan kekeruhan yaitu sekitar 94,2\% untuk waktu tinggal 4 jam, 98,95\% untuk waktu tinggal 3 jam, 98,96\% untuk waktu tinggal 2 jam dan $95,52 \%$ untuk waktu tinggal 1 jam.

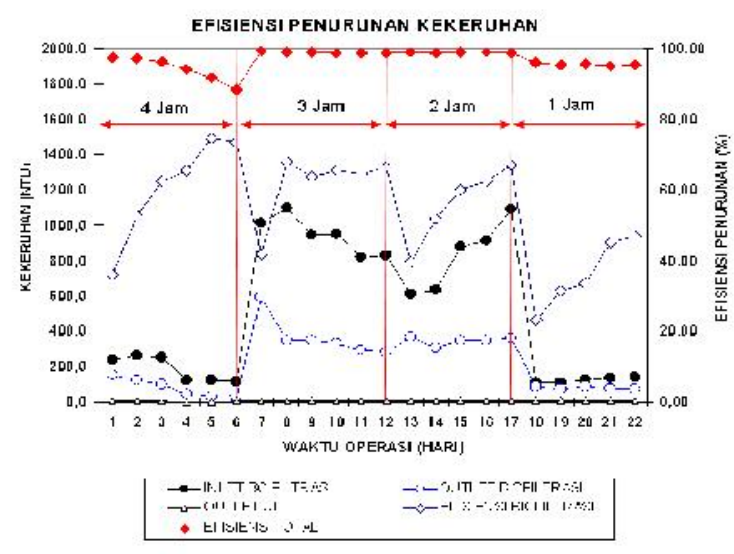

Gambar 5 : Efisiensi Penurunan Kekeruhan

\subsubsection{Pengaruh Waktu Tinggal Hidrolis (WTH) Terhadap Efisiensi Penghilangan Zat Organik}

Zat organik dalam air baku air PAM, berada dalam kondisi tersuspensi maupun terlarut. Untuk meneliti penghilangan zat organik dengan biofiltrasi-ultrafiltrasi dilakukan dengan menganalisa konsentrasi organik permanganat pada inlet dan outlet biofiltrasi, serta pada outlet ultrafiltrasi. Hasilnya seperti yang ditunjukkan pada Gambar 6.

Pada waktu tinggal hidrolis 4 jam yaitu hari 1 sampai hari ke 6 , efisiensi penghilangan zat organik mengalami penurunan dari hari 1 sebesar $65,4 \%$ menjadi $55,24 \%$ hari ke 6 . Ini kemungkinan dikarenakan proses masih dalam tahap pengoperasian awal sehingga mikroba yang berperan menguraikan polutan organik masih belum bekerja optimal. Sedangkan efisiensi penghilangan zat organik untuk keseluruhan sistem biofiltrasi ultrafiltrasi kecenderungannya sama seperti efisiensi biofiltrasi yaitu turun dari hari pertama sampai hari ke 6 . Pada kondisi waktu tinggal 4 jam ini efisiensi total biofiltrasi ultra filtrasi dalam penghilangan zat organik rata-rata adalah $72,9 \%$.

Pada waktu tinggal hidrolis 3 jam yaitu hari ke 7 sampai hari ke 12, efisiensi penghilangan organik untuk reaktor biofiltrasi mengalami kenaikan pada hari pertama yaitu menjadi sekitar $40 \%$, selanjutnya relatif konstan sampai hari ke 12. Sedangkan untuk efisiensi penghilangan zat organik untuk keseluruhan sistem biofiltrasi ultrafiltrasi kecenderungannya naik turun pada kisaran $70 \%$.

Pada waktu tinggal hidrolis 2 jam yaitu hari ke 13 sampai hari ke 17, efisiensi penghilangan organik untuk reaktor biofiltrasi relatif konstan kisaran $25 \%$ pada hari ke 13 sampai hari ke 15 dan mengalami kenaikan sampai dengan 35\% pada hari ke 16 . Kenaikan ini disebabkan karena inlet zat organik pada reaktor biofiltrasi naik. Sedangkan untuk efisiensi penghilangan zat organik untuk keseluruhan sistem biofiltrasi ultrafiltrasi kecenderungannya naik turun pada kisaran 39 sampai $67 \%$.

Pada waktu tinggal 1 jam yaitu hari ke 18 sampai hari ke 22, efisiensi penghilangan zat organik turun menjadi sekitar $23 \%$ pada hari ke 18, selanjutnya mengalami sedikit kenaikan menjadi $46,85 \%$ pada hari ke 22 . Sedangkan untuk total efisiensi biofiltrasi ultrafiltrasi sedikit mengalami penurunan dari $52,84 \%$ pada hari ke 18 menjadi 45,65\% pada hari ke 22. Dari grafik, rata-rata efisiensi penghilangan zat organik untuk total sistem biofiltrasi-ultra filtrasi yang dapat dicapai adalah sekitar $67,5 \%$ untuk waktu tinggal 4 jam, 71,08\% untuk waktu tinggal 3 jam, 67,9\% untuk waktu tinggal 2 jam dan $52,21 \%$ untuk waktu tinggal 1 jam.

Pada waktu tinggal 4 jam, zat organik dapat turun dari rata-rata $10,75 \mathrm{mg} / \mathrm{l}$ menjadi rata-rata sekitar $3,45 \mathrm{mg} / \mathrm{l}$. Pada waktu tinggal 3 jam, zat organik dapat turun dari rata-rata 24,25 $\mathrm{mg} / \mathrm{l}$ menjadi rata-rata sekitar $7,02 \mathrm{mg} / \mathrm{l}$. Pada waktu tinggal 2 jam, zat organik dapat turun dari rata-rata $34,25 \mathrm{mg} / \mathrm{l}$ menjadi rata-rata sekitar $10,99 \mathrm{mg} / \mathrm{l}$. Sedangkan pada waktu tinggal 1 jam, zat organik dapat turun dari rata-rata 11,29 $\mathrm{mg} / \mathrm{l}$ menjadi rata-rata sekitar $5,43 \mathrm{mg} / \mathrm{l}$.

Pada penelitian ini, air baku yang digunakan adalah air sungai sebagai air baku PDAM. Karenanya konsentrasi polutan tidak dapat konstan cenderung berubah-ubah tergantung dari kondisi cuaca saat itu. Untuk itu 
sebagai kriteria disain alat skala plant akan lebih tepat dengan menggunakan data organik loading (beban zat organik) penghilangan zat organik.

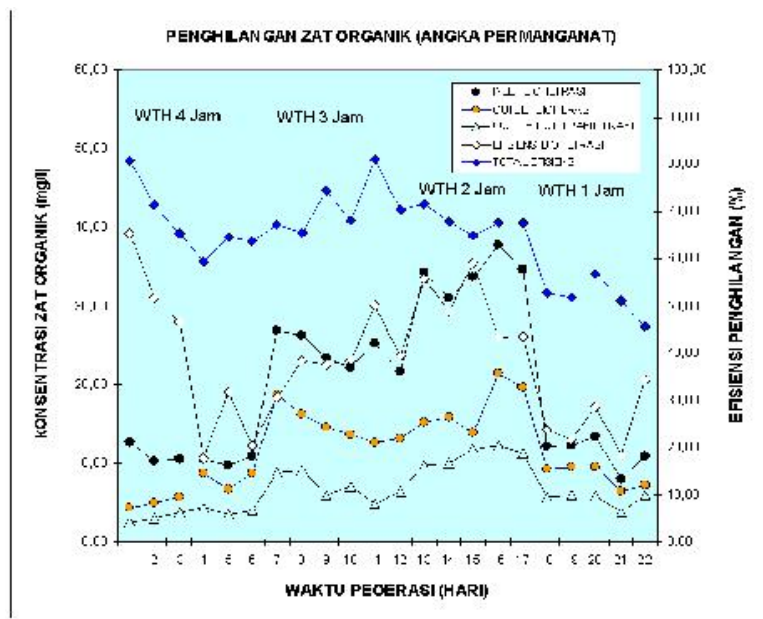

Gambar 6 : Penghilangan Zat Organik

\subsubsection{Pengaruh Zat Organik Loading Terhadap Efisiensi Penghilangan Zat Organik}

Gambar 7 menunjukkan pengaruh zat organik loading terhadap efisiensi penghilangan zat organik. Zat organik loading (dihitung berdasarkan data penelitian yang ada pada Gambar 6. Zat organik loading didefinisikan sebagai hasil kali konsentrasi organik yang masuk ke reaktor $\left(\mathrm{g} / \mathrm{m}^{3}\right)$ dengan debit air yang masuk ke reaktor ( $\mathrm{m}^{3} /$ hari), dibagi dengan volume reaktor biofiltrasi $\left(\mathrm{m}^{3}\right)$.

Dari gambar 7 dapat didapatkan persamaan yang menunjukan hubungan antara zat organik loading dengan efisiensi penghilangan zat organik. Grafik dan persamaan ini dapat digunakan untuk merancang/mendisain alat biofiltrasi skala plant. Semakin besar organik loading, maka volume reaktor yang diperlukan semakin kecil.

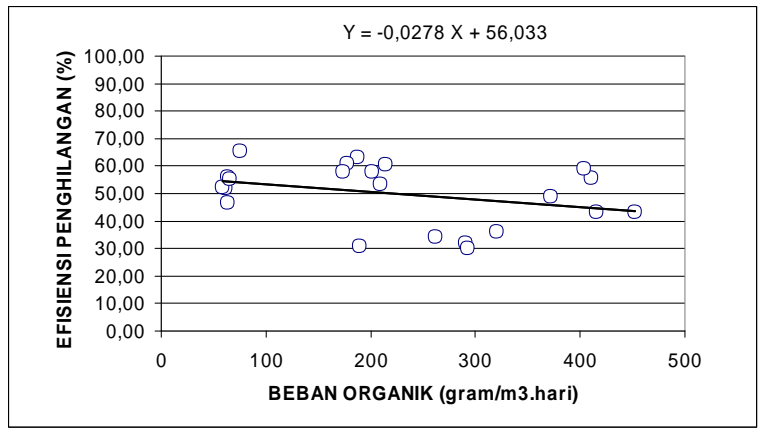

Gambat 7 : Hubungan antara Beban Organik (Organik Loading) Dengan Efisiensi Penghilangan Zat Organik

\subsubsection{Pengaruh Waktu Tinggal Hidrolis (WTH) Terhadap Efisiensi Penghilangan Amoniak}

Amoniak merupakan polutan yang sering ditemui pada air baku yang tercemar. Biasanya kalau konsentrasi polutan organiknya tinggi, polutan amoniaknya juga tingga. Amoniak ini akan berdampak kepada pemakaian klhor sebagai desinfektan yang semakin tinggi pula.

Gambar 8 menunjukkan data amoniak pada penelitian biofiltrasi ultrafiltrasi. Dari gambar dapat terlihat kalau konsentrasi amoniak di inlet sangat berfluktuasi dari yang terendah $0,34 \mathrm{mg} / \mathrm{l}$, sampai tertinggi $1,75 \mathrm{mg} / \mathrm{l}$. Untuk outlet sistem biofiltrasi ultrafiltrasi semuanya berada dibawah $0,5 \mathrm{mg} / \mathrm{l}$

Efisiensi rata-rata yang dapat diperoleh yaitu sebesar $72,8 \%$ untuk waktu tinggal 4 jam, $83,26 \%$ untuk waktu tinggal 3 jam, 69,6\% untuk waktu tinggal 2 jam dan $63,8 \%$ untuk waktu tinggal 1 jam. Dapat disimpulkan bahwa penurunan amoniak paling bagus terjadi pada kondisi waktu tinggal hidrolik 3 jam. Pada kondisi ini konsentrasi amoniak dapat turun dari sekitar $1,75 \mathrm{mg} / \mathrm{l}$ sampai menjadi sekitar $0,26 \mathrm{mg} / \mathrm{l}$.

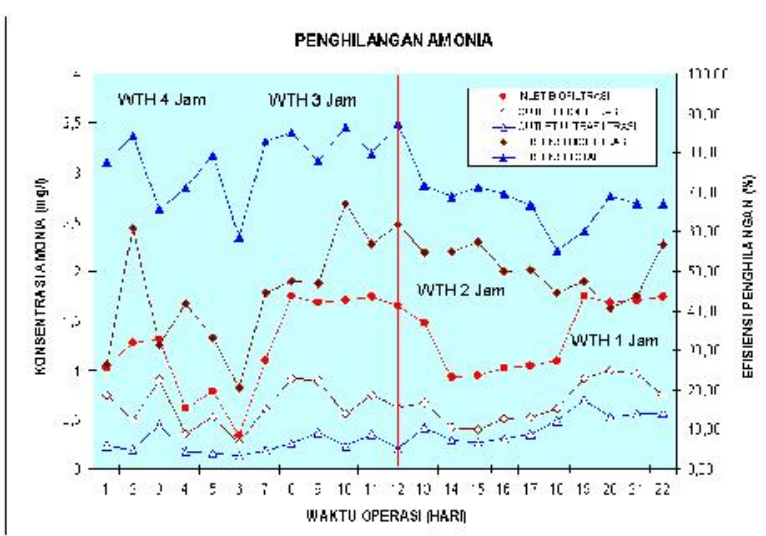

Gambar 8 : Efisiensi Penghilangan Amoniak

\section{KESIMPULAN}

Sistem pengolahan air dengan menggunakan proses biofiltrasi ultra filtrasi dapat dipergunakan sebagai alternatif untuk mengolah air baku air minum yang telah tercemar oleh kekeruhan, amoniak maupun zat organik seperti yang terjadi pada kebanyakan air sungai di DKI jakarta. Dari data penelitian yang telah dilakukan selama hampir satu bulan dengan menggunakan prototipe alat kapasitas $50 \mathrm{~m}^{3}$ per hari, dapat disimpulkan sebagai berikut:

Efisiensi penghilangkan kekeruhan yaitu sekitar 94,2\% untuk waktu tinggal 4 jam, 98,95\% untuk waktu tinggal 3 jam, 98,96\% untuk waktu tinggal 2 jam dan 95,52\% untuk 
waktu tinggal 1 jam. Tingkat kejernihan air yang dapat dicapai adalah dibawah 4 NTU.

Efisiensi penghilangan zat organik untuk total sistem biofiltrasi-ultra filtrasi yang dapat dicapai adalah sekitar $67,5 \%$ untuk waktu tinggal 4 jam, 71,08\% untuk waktu tinggal 3 jam, 67,9\% untuk waktu tinggal 2 jam dan 52,21\% untuk waktu tinggal 1 jam. Untuk waktu tinggal 3 jam, konsentrasi zat organik dapat turun dari rata-rata 24,25 mg/l menjadi rata-rata sekitar 7,02 mg/l.

Efisiensi rata-rata yang dapat diperoleh untuk penghilangan amoniak adalah sebesar $72,8 \%$ untuk waktu tinggal 4 jam, 83,26\% untuk waktu tinggal 3 jam, 69,6\% untuk waktu tinggal 2 jam dan 63,8\% untuk waktu tinggal 1 jam. Dapat disimpulkan bahwa penurunan amoniak paling bagus terjadi pada kondisi waktu tinggal hidrolik 3 jam. Pada kondisi ini konsentrasi amoniak dapat turun dari sekitar $1,75 \mathrm{mg} / \mathrm{l}$ sampai menjadi sekitar 0,26 mg/l.

Dengan mempertimbangkan ketiga faktor polutan yang ada pada air baku, maka disarankan untuk mendisain alat biofiltrasi ultrafiltrasi skala plant, waktu tinggal yang digunakan adalah 2-3 jam. Pertimbangannya adalah pada kondisi ini efisiensi penghilangan polutan untuk ketiga parameter tersebut adalah paling tinggi. Pertimbangan lain adalah konsentrasi polutan air hasil olahan yang sudah cukup rendah dibandingkan dengan pada kondisi waktu tinggal yang lain.

\section{DAFTAR PUSTAKA}

1. Horan, N.J.(1990). "Biological Wastewater Treatment systems : Theory and Operation". University of Leeds, England. John Wiley \& Sons Ltd.

2. JICA:" Water Supply Engineering VOL.I ", Edited By Japan Water works Association.

3. Lykins,B.W., Moser, R., DeMacro, J. "Treatment Technology in The United States, Disinfection And Controls Of Disinfection By Product", The second Japan - US Governmental Conference On drinking water Quality Management, July 24-26, 1990, Tokyo, japan.

4. Bitton G. (1994), "Wastewater Microbiology". Wiley-Liss, New York.

5. Reynold, Tom D., "Unit Operations and Processes in Environmental Engineering", $\mathrm{B} / \mathrm{C}$ Enginering, United State Of America, 1982.

6. Grady, C.P.L and Lim, H.C.(1980). "Biological Wastewater Treatment", Marcel Dekker Inc. New York.

7. Metclaf And Eddy , "Waste Water Engineering", Mc Graw Hill 1991.

8. Hikami, Sumiko., "Shinseki rosohou ni yoru mizu shouri gijutsu (Water Treatment with Submerged Filter)", Kougyou Yousui No.411, 12,1992 .

\section{LAMPIRAN}

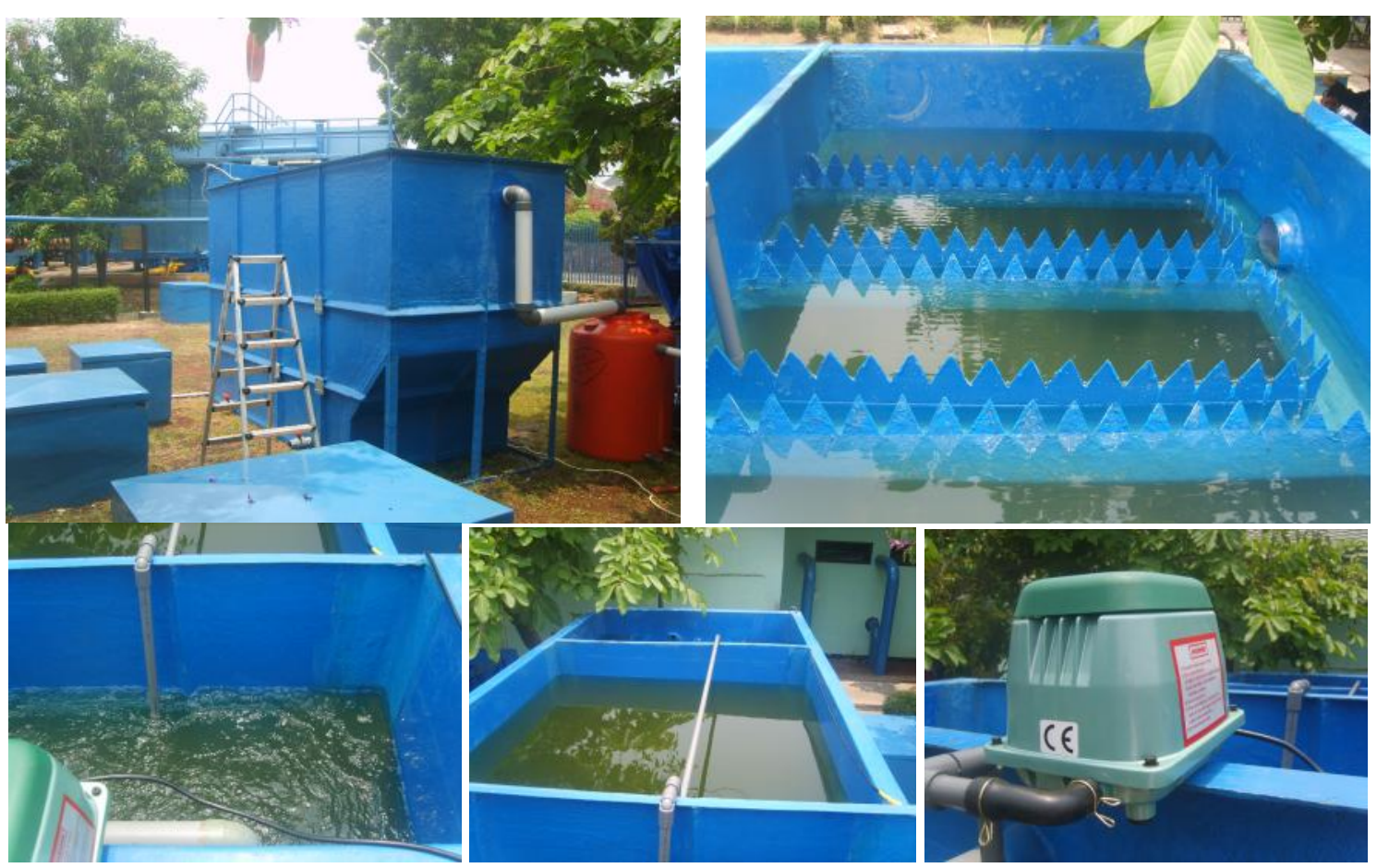

Gambar 9 : Reakror Biofiltrasi Yang sedang Beroperasi 


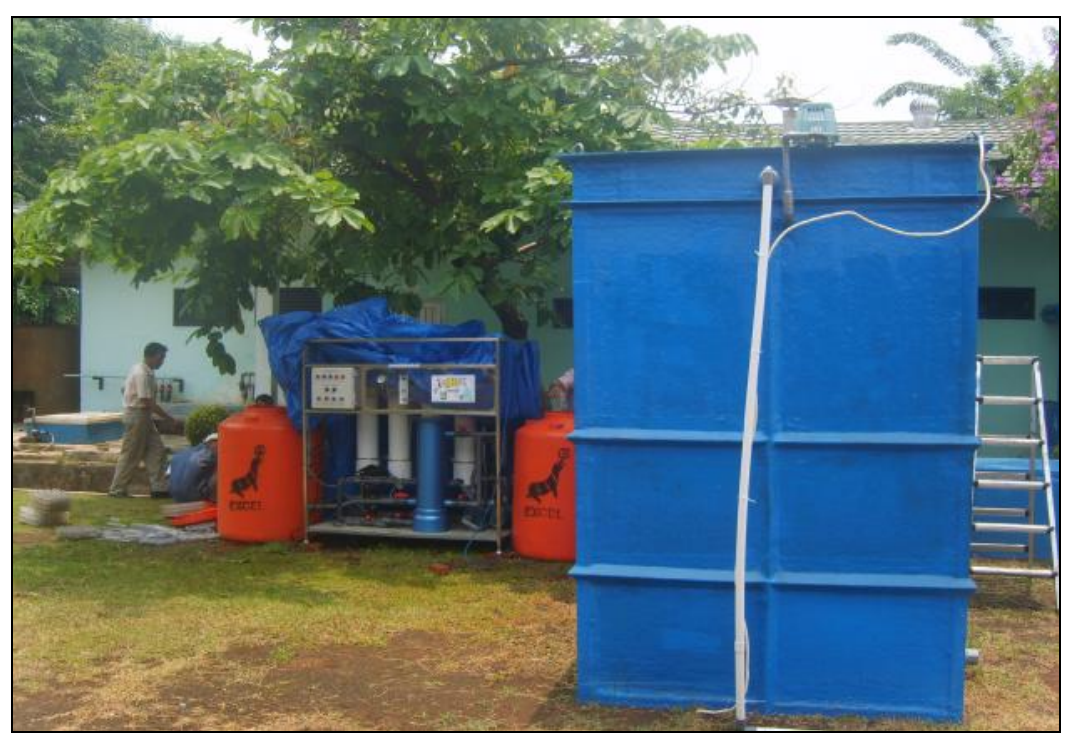

Gambar 10 : Ujicoba Pengolahan Air Minum Dengan Proses Biofiltrasi Dan Ultrafiltrasi di PAM Taman Kota, Jakarta.
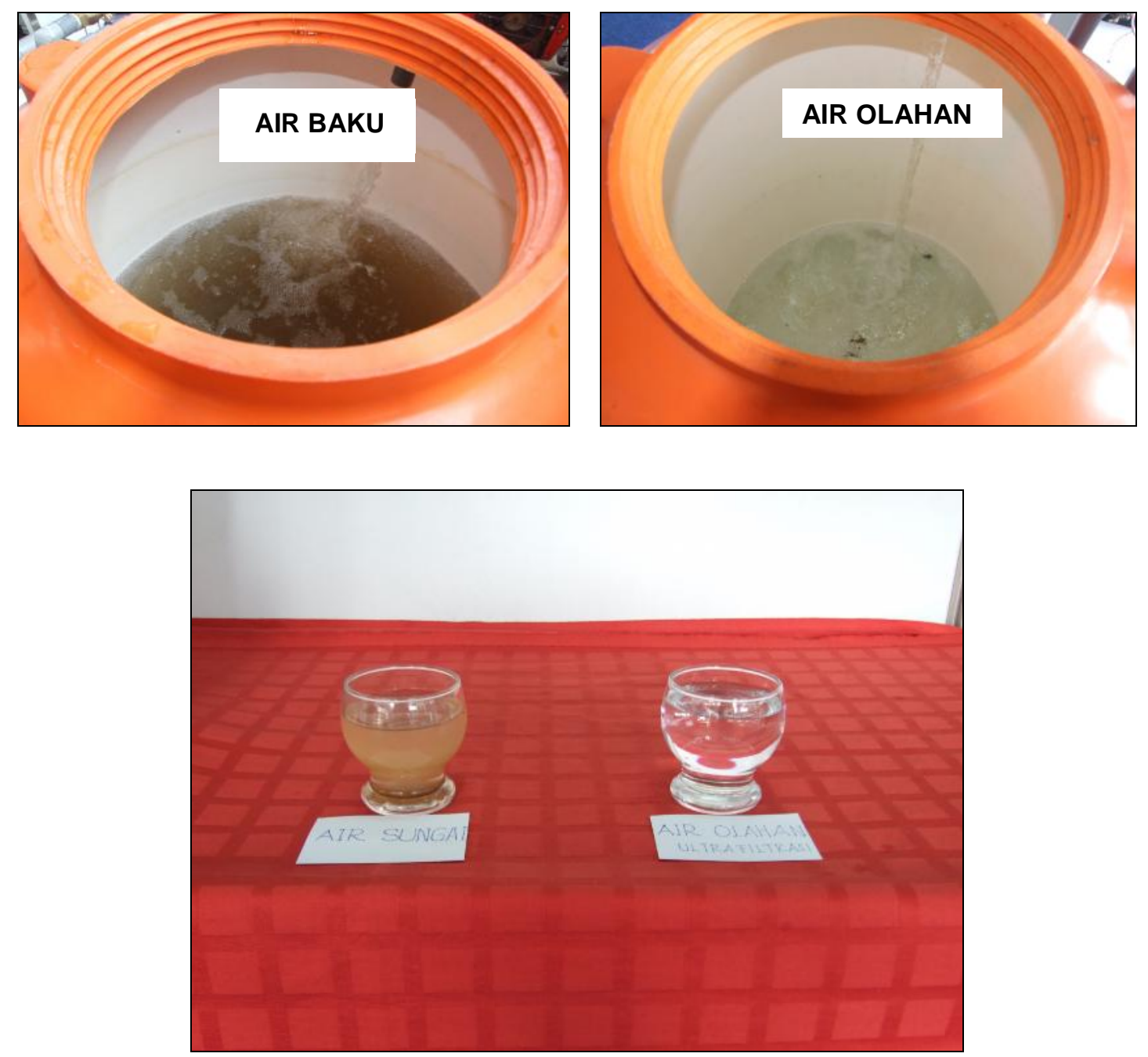

Gambar 11 : Air Baku dan Air Olahan 


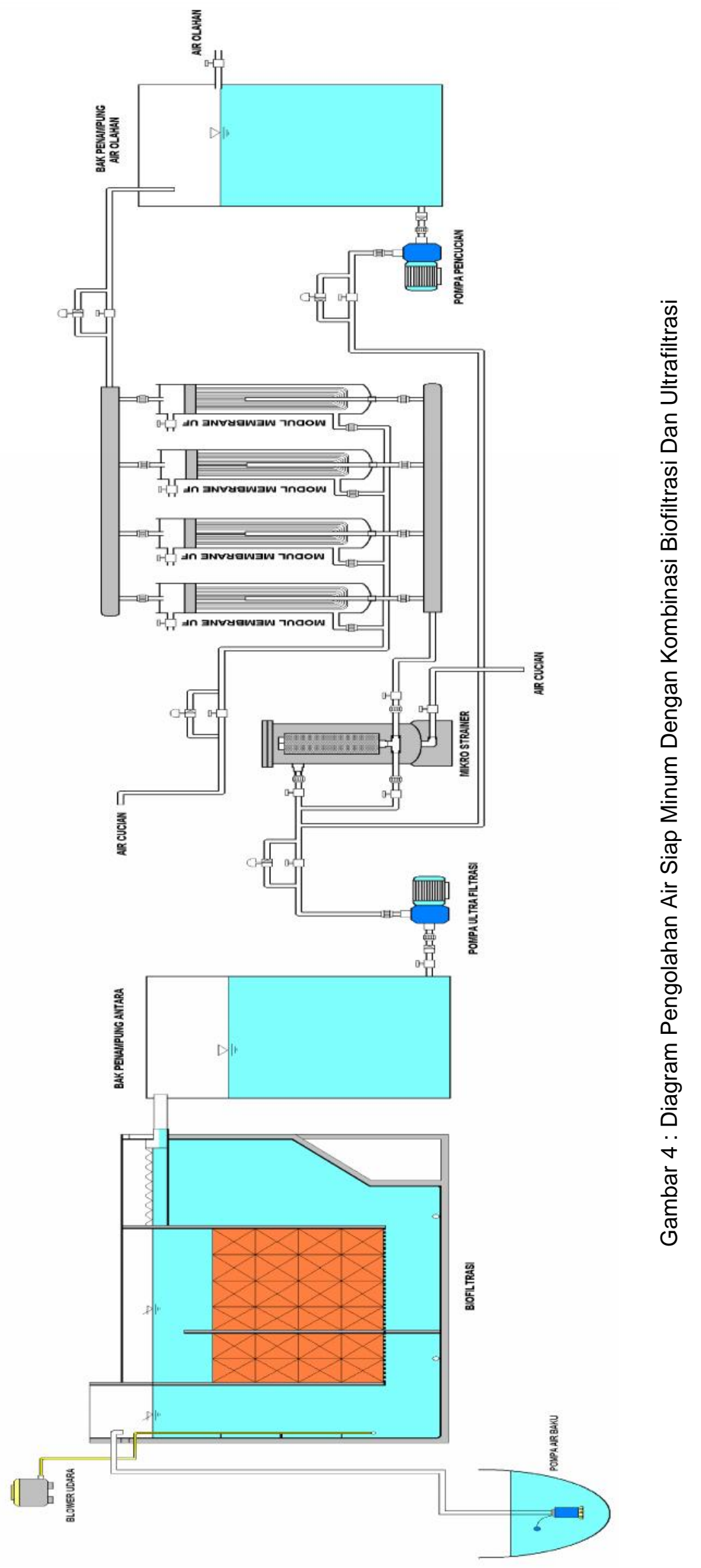

